

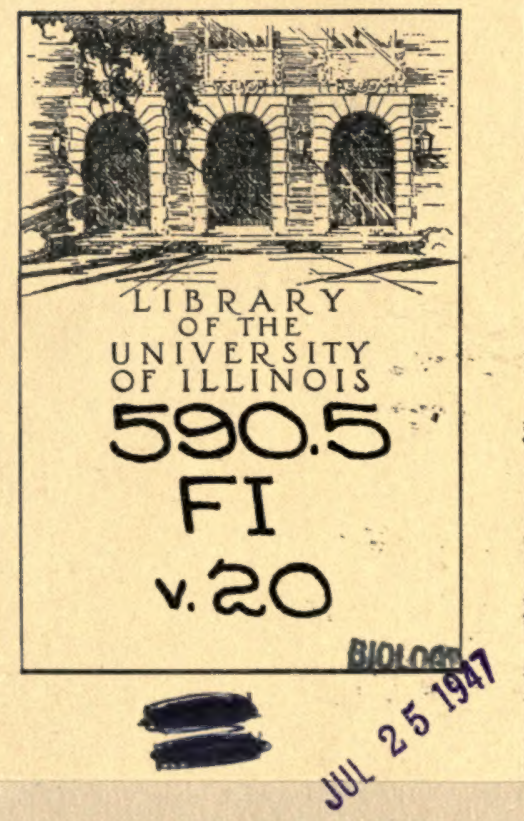




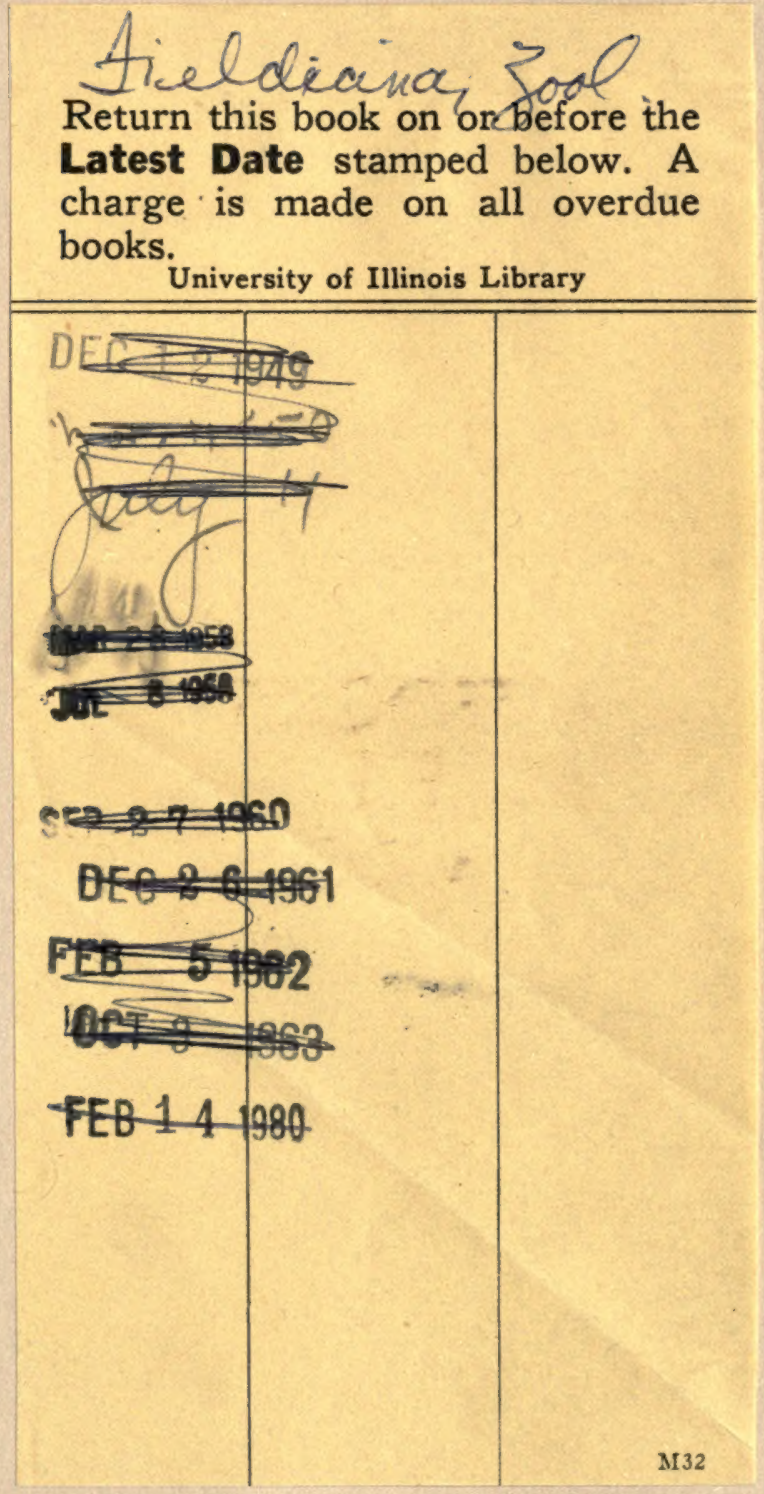







\section{ZOOLOGICAL SERIES}

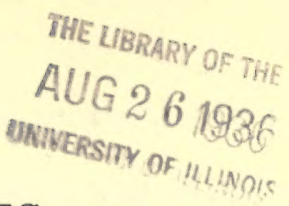

of

FIELD MUSEUM OF NATURAL HISTORY

Volume XX

Chicago, August 15, 1936

No. 14

\section{DESCRIPTIONS AND RECORDS OF AFRICAN BATS \\ By Colin Campbell Sanborn Assistant Curator of Mammais}

This paper contains a complete list of the bats collected by the Straus West African Expedition and descriptions and notes on others collected by the Conover-Everard African and Chicago Daily News Abyssinian Expeditions of Field Museum. The taking of certain forms in French Sudan and Nigeria which were known only from Belgian Congo is of special interest.

I am indebted to Mr. Gerrit S. Miller, Jr., and to Dr. H. E. Anthony for the loan of many specimens.

\section{Eidolon helvum Kerr.}

Vespertilio vampyrus helvus Kerr, Animal Kingdom, 1, part 1, pp. xvii, 91, No. 108, 1792 - Senegal.

Senegal: Sine-Saloum, Fatick, 11 males (1 skeleton), 12 females (2 skeletons), February 19, 1934, F. C. Wonder.

Epomophorus gambianus Ogilby.

Pteropus gambianus Ogilby, Proc. Zool. Soc. Lond., p. 100, 1835-Gambia.

French Sudan: Sotuba, $7 \mathrm{~km}$. east of Bamako, 10 males (1 alc., 1 skeleton), 26 females ( 9 alc., 3 skeletons), March 25-April 6, 1934, F. C. Wonder.

Rousettus aegypticus Geoffroy.

Pleropus aegypticus Geoffroy, Ann. Mus. d'Hist. Nat., 15, p. 96, 1810-Lower Egypt.

Cameroon Mandate: Buea, Mount Cameroon, 3,000 feet, male, female, June 21, 1934, female, July 15, 1934, R. and L. Boulton.

This species has been taken in the Gaboon but never quite so far west as Nigeria.

Nycteris thebaica gambiensis K. Andersen.

Petalia gambiensis K. Andersen, Ann. Mag. Nat. Hist., (8), 10, p. 548, 1912 -Dialocote, French Gambia. 
Senegal: Kedougou, 14 males ( 6 alc., 2 skeletons), 25 females (13 alc., 1 skeleton), May 19-20, 1934, F. C. Wonder.

Rhinolophus alcyone alticolus subsp. nov.

Type from cave at 5,800 feet on Mount Cameroon, Cameroon Mandate. No. 42596 Field Museum of Natural History. Adult female. Collected July 2, 1934, by R. and L. Boulton.

Diagnosis.-A member of the landeri group with reduced second phalanx of fourth finger. Like alcyone but much smaller. With the exception of the ears, which are larger, about the size of lobatus. Skull with characters of alcyone; size of lobatus, but narrower.

Color.-General color of upper parts dark brown, between Raw Umber and Mummy Brown (Ridgway, 1912). Base of hairs much lighter. Below brownish gray.

Skull.-As in alcyone in that $\mathrm{p}_{\overline{3}}$ is partly in tooth-row and separates $\mathrm{p}_{\overline{2}}$ and $\mathrm{p}_{\overline{4}}$, but much smaller. Length as in lobatus, but with shorter tooth-rows and narrower throughout.

Measurements.-Type and three topotypes: forearm 46.2 (46.247.1); third digit metacarpal 31.8, first phalanx 14.3, second phalanx 25.5; fourth digit metacarpal 34.6 , first phalanx 7.7 , second phalanx 15.7; fifth finger metacarpal 35, first phalanx 10.1, second phalanx 17.7. Ear, from meatus 22, from crown (dry) 15, width (dry) 14.1 . Tibia 17.3; foot 9; calcar 11.9. Skull: total length 19.2 (19.2-19.6); total length to canine 18.5 (18.4-18.9); basilar length to canine 14.9 (14.7-15); interorbital width 2.4 (2.4-2.5); zygomatic width 9 (99.1); mastoid width 9.1 (9-9.1); width of brain case 8 (7.9-8); width across canines $4.4(4.3-4.5)$; width across $\mathrm{m}^{3}-\mathrm{m}^{3}, 6.4(6.3-6.4)$; width of nasal swelling 4.8 (4.8-4.9); upper tooth-row $\mathrm{c}-\mathrm{m}^{3}$, 6.6 (6.6-6.7); lower tooth-row $\mathrm{c}-\mathrm{m}_{\overline{3}}, 6.9$ (6.7-6.9); mandible 11.9 (11.8-12.1).

Specimens examined.-Type and three topotypes.

Remarks.-This race appears to be a highland form most closely related to alcyone and a western representative of lobatus from East Africa. Thomas (Ann. Mag. Nat. Hist., (8), 7, p. 458, 1911) listed a Rhinolophus from Panyon (4,000 feet), Nigeria, as "near $R$. alcyone" which may be the same. Andersen (Ann. Mus. Civ. Stor. Nat., Genova, (3), 2, p. 190, 1905-06) has published an excellent series of measurements of this group.

Hipposideros caffer guineensis K. Andersen.

Hipposideros caffer guineensis K. Andersen, Ann. Mag. Nat. Hist., (7), 17, p. 278, 1906-Como River, 70 miles from Gaboon, French Congo. 
Cameroon Mandate: Mount Cameroon, 3 skins (no sex), June 21, 1934, 1 male, 6 females alc., July 15, 1934, R. and L. Boulton.

\section{Hipposideros tephrus Cabrera.}

Hipposideros tephrus Cabrera, Bol. Real Soc. Espan. Hist. Nat., 6, p. 358, 1906 -Mogador, Morocco.

French Sudan: Sotuba, $7 \mathrm{~km}$. east of Bamako, 1 female, April 8, 1934, F. C. Wonder.

This specimen is but a fraction smaller than measurements given by Andersen (Ann. Mus. Civ. Stor. Nat., Genova, (3), 3, p. 16, 1907) for specimens from Nubia, Gold Coast, and Farim. Thomas (Nov. Zool., 27, p. 315, 1920) lists specimens from Kano, Nigeria.

\section{Pipistrellus culex Thomas.}

Pipistrellus culex Thomas, Ann. Mag. Nat. Hist., (8), 7, p. 458 1911-Kabir, Plateau Province, Nigeria.

Nigeria: Ifon, Ondo Province; 4 males (1 alc.), 5 females ( 2 alc.), August 6 and 8, 1934, R. and L. Boulton.

These specimens, with forearms measuring from 26 to $28.5 \mathrm{~mm}$., agree well with the description and measurements of this species.

\section{Scotophilus nigritellus de Winton.}

Scotophilus nigritellus de Winton, Ann. Mag. Nat. Hist., (7), 4, p. 355, 1899 - Gambaga, northern Gold Coast.

French Sudan: Sotuba, $7 \mathrm{~km}$. east of Bamako, 3 males (2 alc.), April 12, 1934, F. C. Wonder.

These are provisionally referred to nigritellus although they are much lighter in color than the type as described, but the three specimens show a great variety of color among themselves. The skin is between Wood Brown (Ridgway, 1912) and Avellaneous. One alcoholic is between Hair Brown and Drab, and the other alcoholic is dirty whitish, darker on the head, and may be albinotic. All are pure white below with the exception of one alcoholic that is Wood Brown on throat and chin. The forearms measure 42.3 to $43.2 \mathrm{~mm}$., and the one skull cleaned is just slightly smaller than the measurements given for the type.

Bamako is about 500 miles west and a little north of Gambaga, the type locality, and is in the Sudan arid region. Gambaga is just on the edge of this region. The species has been taken near Badi, Gambia (Thomas, Ann. Mag. Nat. Hist., (8), 8, p. 118, 1911), one male, and in southeastern Nigeria (Wroughton, Ann. Mag. Nat. Hist., (7), 17, p. 375, 1906), one male. 


\section{Field Museum of Natural History-Zoology, Vol. XX}

\section{Glauconycteris alboguttatus J. A. Allen.}

Glauconycteris alboguttatus J. A. Allen, Bull. Amer. Mus. Nat. Hist., 37, p. 449, 1917-Medje, northeastern Belgian Congo.

Nigeria: Ifon, Ondo Province, 2 males alc., August 5, 2 males, 1 female, August 7, 1934, R. and L. Boulton.

These appear to be slightly smaller and much lighter than the type but in general agree fairly well with the original description. While a long way from the type locality, Ifon is also in the lower Guinea Forest region of Chapin but in the northwestern corner.

In the least worn and darkest specimen the lower back is close to Dresden Brown (Ridgway, 1912), which lightens to between Drab and Mouse Gray on the shoulders and head. In two other specimens which are more worn the color becomes much lighter, in general almost a grayish white due to the wearing off of the brownish tips to the hairs. There is no white on the propatagium and outer border of the wing, nor on the under side of the forearm and phalanges. The bases of the hairs are dark, close to Seal Brown, which is the color given for the type.

The skull is about a millimeter shorter than the measurements given for the type but is just as broad. The upper incisors are bicuspid and have a projection rising from the inner posterior base, which, at some angles, gives a tricuspid appearance to the teeth.

\section{Miniopterus inflatus Thomas.}

Miniopterus inflatus Thomas, Ann. Mag. Nat. Hist., (7), 12, p. 634, 1903 -Efulen, Cameroon.

Cameroon Mandate: Mount Cameroon, 5,800 feet, 7 males (4 alc.), 2 females ( 1 alc.), July 2, 1934, R. and L. Boulton. Collected in cave with Rhinolophus alcyone alticolus.

These specimens agree with the color description of the type but are somewhat smaller. They are even smaller than those recorded from Thysville in the lower Congo by J. A. Allen. This is the third record of the species and extends its range to the north.

Measurements.-Forearm 42.2-45.4 (type 46); greatest length of skull 15-15.3 (16.7); front of incisors to back of $\mathrm{m}^{3}, 6.9(7.8)$.

Miniopterus natalensis arenarius Heller.

Miniopterus natalensis arenarius Heller, Smiths. Misc. Coll., 60, p. 2, 1912Guaso Nyuki, northern Guaso Nyiro River, Kenya Colony.

Miniopterus natalensis vicinior J. A. Allen.

Miniopterus breyeri vicinior J. A. Allen, Bull. Amer. Mus. Nat. Hist., 37, p. 451, 1917-Aba, northeastern Belgian Congo. 
Through the kindness of Mr. Gerrit S. Miller, Jr., and Dr. H. E. Anthony I have been able to examine the types and series of topotypes of these forms, and I must agree with Roberts (Ann. Trans. Mus., 4, p. 68, 1913) that breyeri is a synonym of natalensis.

There is practically no difference in size between natalensis (forearm 45-47), arenarius (44-46.1), and vicinior (42.6-44.6). $M$. arenarius is as much darker (although stated in the original description to be lighter) as vicinior is lighter, than natalensis. Each represents a very slightly smaller color phase of the original species. I have not seen dasythryx, fraterculus, or smitianus, but they may also be but color phases of natalensis, which seems to differ from schreibersi mainly in color.

The European form of Miniopterus (schreibersi), the Persian form (s. pallidus), and the African forms (natalensis, arenarius, vicinior, dasythrix, fraterculus, smitianus, and inflatus) have forearms of about the same length, from 43 to $47 \mathrm{~mm}$., and upper tooth-rows from 5 to $6 \mathrm{~mm}$. Also in the skulls the mastoid width is about equal to or generally greater than the zygomatic width.

The Asiatic forms, however, described as subspecies of schreibersi (blepotis, magnater, chinensis, parvipes, japoniae) and the Indian form (fuliginosus) are all larger, with forearms from 47 to 51 and upper tooth-rows between 6 and $7 \mathrm{~mm}$. in length. Also the shape of the skull changes and the zygomatic width is greater than the mastoid width. I have not been able to examine all of these forms, but if future studies should prove that this character is constant, as is indicated, it might be advisable to consider the Asiatic forms as subspecies of blepotis rather than of schreibersi.

There are two forms in Africa, however, which are described below, and which agree in size and character with the Asiatic forms. Until a more intensive study can be made of the genus it seems best to consider these as species.

\section{Miniopterus africanus sp. nov.}

Type from Sanford's Ranch, Mulo, northwest of Addis Ababa, Shoa District, Ethiopia. Altitude 8,000 feet. No. 28769 Field Museum of Natural History. Adult female. Collected October 25, 1926, by A. M. Bailey. Orig. No. 73.

Diagnosis.-In general like natalensis but much larger. Skull and teeth larger. Zygomatic width greater than mastoid width.

Color.-Type, general color above very light Fuscous, bases of hairs Fuscous with light tips. Chin and throat dark where worn. 
Rest of under parts light, hairs Fuscous basally with gray tips. A few light gray hairs in pubic region.

A male and female topotype are practically like the type. Three other female topotypes have the head and shoulders near Natal Brown and the back near Clove Brown, some hairs with gray tips. The under parts are as in the type but browner.

Skull.-Large, with zygomatic width greater than mastoid width. Sagittal crest low. Teeth large.

Measurements.-Type and topotypes: forearm 50.4 (48.4-50.5). Skull: greatest length 16.9 (16.6-17); condylo-basal length 16.1 (16-16.5); palatal length 7.8 plus (8.2-8.8); interorbital width 4.2 (4.1-4.2); zygomatic width 9.4 (9-9.5); mastoid width 8.9 (8.7-9.1); width of brain case 8.3 (8.4-8.5); width across canines 5 (5-5.1); width across $\mathrm{m}^{2}-\mathrm{m}^{2}, 7.1$ (6.9-7.1); upper tooth-row $\mathrm{c}-\mathrm{m}^{3}$, 6.6 (6.46.6); lower tooth-row $\mathrm{c}-\mathrm{m}_{\overline{3}}, 7$ (7-7); length of mandible 12.5 (12.212.7). Two alcoholic specimens from Kenya Colony: forearm 49.649.7; second digit metacarpal 45.9-45.9; third digit metacarpal 45.6-46.5, first phalanx 11.4-11.8, second phalanx 32.1-33.5, tip 6-6.5; fourth digit metacarpal 44.8, first phalanx 9-9.4, second phalanx 17-17.1; fifth digit metacarpal 40.6-41, first phalanx 9.8-10.6, second phalanx 7.6-7.6. Tibia 21.3-21.5; foot 11-11.

Specimens examined.-Type and five topotypes (six skins with five skulls) and two specimens in alcohol from Ulukenia Hills, Kenya Colony (U. S. Nat. Mus. Nos. 166595-96).

Remarks.-The large size and the color added to the more widely expanded zygoma will separate this form from all other African Miniopterus. Heuglin (Reise in Nord. Afrika, 2, p. 32, 1877) records a Minioplerus from Lake Tana which was identified by Peters as M.dasythrix of south and southwest Africa. His specimen may belong here but it is not recognizable from the description.

\section{Miniopterus rufus sp. nov.}

Type from Katobwe, 40 miles below Bukama on the Lualaba River, Tanganyika-Moero, Belgian Congo. No. 29416 Field Museum of Natural History. Adult male. Collected November 28, 1926, by J. T. Zimmer. Orig. No. 566 .

Diagnosis.-About the size of $M$. africanus but with shorter forearm and tibia and of a reddish brown color.

Color.-Reddish brown, between Kaiser and Carob Brown (Ridgway, 1912), slightly lighter below. Hairs uniform to bases. 
Skull.--In general like africanus but narrower and with lambdoid and sagittal crests more developed and mandible heavier.

Measurements.-Forearm 47.4. Skull: greatest length 16.9; condylo-basal length 15.9 ; palatal length 8.7 ; interorbital width 4.1 ; zygomatic width 9.4 ; mastoid width 9.1 ; width of brain case 8.2 ; width across canines 5 ; across $\mathrm{m}^{2}-\mathrm{m}^{2}, 6.7$; upper tooth-row $\mathrm{c}-\mathrm{m}^{3}$, 6.4 ; lower tooth-row $\mathrm{c}-\mathrm{m}_{\overline{3}}, 7$; length of mandible 12.8 .

Remarks.-While there is but one specimen, the type, the character of the skull and the very different color seem to be of enough importance to separate this form from other African Miniopterus. There seems to be no red phase in this genus as in Hipposideros, Myotis, and others, but there has been another Miniopterus described which is of about this color, M. ravus Sody, of central Java.

\section{Chaerephon gambianus de Winton.}

Nyctinomus gambianus de Winton, Ann. Mag. Nat. Hist., (7), 7, p. 39, 1901 - Gambia.

Senegal: Kedougou, 2 males ( 1 skull only), 4 females ( 2 alc.), May 18, 1934, F. C. Wonder. French Sudan: Sotuba, $7 \mathrm{~km}$. east of Bamako, 7 males (4 alc.), 12 females (10 alc.), March-April, 1934, F. C. Wonder.

There are three forms in West Africa to which these specimens might be referred but as they do not agree fully with any of the rather inadequate descriptions, the oldest one is used until comparisons can be made with $C$. websteri Dollman (Ann. Mag. Nat. Hist., (8), 2, p. 546, 1908) from Nigeria and $C$. nigri Hatt (Bull. Soc. Zool. France, 53, p. 374, 1928) from Timbuktu, French Sudan.

In this series the general color is brownish above and lighter below due to the gray tipping to the hairs. On the under side of the wing membrane is a line of white next the body from femur to groin, this being more pronounced in some specimens than in others.

The size and position of the anterior upper premolar is varied. In no specimen could it be called minute. Its position varies with the spacing between the canine and the second premolar; the closer these teeth the more crowded outward the first premolar.

Measurements.-Forearm 35-37.7, gambianus 37-40, nigri 35.536, websteri 34.5-36. Total length of skull 15.7-16.4, gambianus 16.7, nigri 16, websteri 15.4-15.9.

Chaerephon abae J. A. Allen.

Chaerephon (Lophomops) abae J. A. Allen, Bull. Amer. Mus. Nat. Hist., 37, p. 464, 1917-Aba, northeastern Belgian Congo. 


\section{Field Museum of Natural History-Zoology, Vol. XX}

French Sudan: Sotuba, $7 \mathrm{~km}$. east of Bamako, 1 male, 4 females (1 alc., 1 skeleton, 1 skull only), March 21 and April 5, 1934, F. C. Wonder.

Although a long way from the type locality, these specimens agree fully with the description and measurements of the type series. In the alcoholic specimen the entire center of the lower belly is white instead of having only a narrow white line. Both Sotuba and Aba are in the open, bush-veldt country.

Mops angolensis wonderi subsp. nov.

Type from Sotuba, $7 \mathrm{~km}$. east of Bamako, French Sudan. No. 42138 Field Museum of Natural History. Adult female. Collected April 13, 1934, by Frank C. Wonder. Orig. No. 814.

Diagnosis.-Like $M$. angolensis but smaller and with lightercolored under parts.

Color.-Type: upper parts dark brown, lighter on head and very strongly flecked with gray. A broad, almost hairless collar across shoulders. Below brownish gray on throat and chin; center of belly and sides of body from femur to groin white. Between these white areas, dark gray. Other specimens show more dark gray below and in one there is a rather spotted line of brown, but in all the sides of the body are white from femur to groin.

Skull.-Probably smaller than in angolensis, for which I can find no measurements, and shorter, with a narrower zygomatic width, and a much shorter lower tooth-row than in $M$. a. niveiventer Cabrera and Ruxton. Sagittal and lambdoid crests well developed and preorbital processes distinct. Anterior upper premolar minute.

Measurements.-Forearm 45.7 (44.8-48.5; 5 skins 44.8-47.8, 3 skeletons 46-47.5, one alc. 48.5). Skull: greatest length 20.9 (20.121.8); condylo-basal length 17.9 (17.9-18.8); palatal length 8.6 (8.6-8.8); interorbital width $4.5(4.5-4.7)$; zygomatic width 12.6 (12.4-13.1); mastoid width 11.8 (11.7-12.2); width of brain case 10.4 (10.3-10.5); width across canines $6(6-6.5)$; across $\mathrm{m}^{2}-\mathrm{m}^{2}, 8.7$ (8.6-9.1); upper tooth-row $\mathrm{c}^{-\mathrm{m}^{3}}$, 7.3 (7.3-7.8); lower tooth-row $\mathrm{c}-\mathrm{m}_{\overline{3}}, 8$ (8-8.6); length of mandible 13.5 (13.5-14.6). Measurements of alcoholic specimen: forearm 48.5; second digit 47.3; third digit metacarpal 50.9, first phalanx 22.9, second phalanx 23.6, tip 12; fourth digit metacarpal 49 , first phalanx 20.5, second phalanx 18.8; fifth digit metacarpal 33.5, first phalanx 13.2, second phalanx 6.4. Ear, from meatus 15, from crown 12.6. Tibia 17.1, foot 13 . 





UNIVERSITY OF ILLINOIS-URBANA

$590.5 F 1$

FIELDIANA, 200LOGYSCHGO

20 1933-38

|||||||||||||||||||||||||||||||||||||||||||||||||||||||||||||

30112009379493 